Hellen Cristina de Almeida Abreu'

\section{Annelita Almeida Oliveira}

Reiners ${ }^{1}$

Rosemeiry Capriata de Souza

Azevedo

Ageo Mário Cândido da Silva"

Débora Regina de Oliveira

Moura Abreu'

Adriana Delmondes de Oliveira'

\title{
Incidence and predicting factors of falls of older inpatients
}

\section{Incidência e fatores preditores de quedas de idosos hospitalizados}

\section{ABSTRACT}

OBJECTIVE: To estimate the incidence and predicting factors associated with falls among older inpatients.

METHODS: Prospective cohort study conducted in clinical units of three hospitals in Cuiaba, MT, Midwestern Brazil, from March to August 2013. In this study, 221 inpatients aged 60 or over were followed until hospital discharge, death, or fall. The method of incidence density was used to calculate incidence rates. Bivariate analysis was performed by Chi-square test, and multiple analysis was performed by Cox regression.

RESULTS: The incidence of falls was 12.6 per 1,000 patients/day. Predicting factors for falls during hospitalization were: low educational level $(\mathrm{RR}=2.48$; $95 \% \mathrm{CI} 1.17 ; 5.25)$, polypharmacy $(\mathrm{RR}=4.42 ; 95 \% \mathrm{CI} 1.77 ; 11.05)$, visual impairment $(\mathrm{RR}=2.06 ; 95 \% \mathrm{CI} 1.01 ; 4.23)$, gait and balance impairment $(\mathrm{RR}=2.95 ; 95 \% \mathrm{CI} 1.22 ; 7.14)$, urinary incontinence $(\mathrm{RR}=5.67$; $95 \% \mathrm{CI} 2.58 ; 12.44)$ and use of laxatives $(\mathrm{RR}=4.21 ; 95 \% \mathrm{CI} 1.15 ; 15.39)$ and antipsychotics (RR $=4.10 ; 95 \% \mathrm{CI} 1.38 ; 12.13)$.

CONCLUSIONS: The incidence of falls of older inpatients is high. Predicting factors found for falls were low education level, polypharmacy, visual impairment, gait and balance impairment, urinary incontinence and use of laxatives and antipsychotics. Measures to prevent falls in hospitals are needed to reduce the incidence of this event.

DESCRIPTORS: Aged. Accidental Falls. Risk Factors. Cohort Studies.
Faculdade de Enfermagem. Universidade Federal de Mato Grosso. Cuiabá, MT, Brasil

Instituto de Saúde Coletiva. Universidade Federal de Mato Grosso. Cuiabá, MT, Brasil

Correspondence:

Annelita Almeida Oliveira Reiners

Rua Zulmira Canavarros, 313 Centro

78005-200 Cuiabá, MT, Brasil

E-mail: reiners17@hotmail.com 


\section{RESUMO}

OBJETIVO: Estimar a incidência e fatores preditores de quedas de idosos hospitalizados.

MÉTODOS: Estudo de coorte prospectivo realizado em unidades de clínica médica de três hospitais de Cuiabá, MT, no período de março a agosto de 2013. Foram acompanhadas 221 pessoas com 60 anos ou mais internadas até a alta, óbito ou queda. Para o cálculo das taxas de incidência utilizou-se o método de densidade de incidência. Realizou-se análise bivariada pelo teste do Qui-quadrado e múltipla por meio de regressão Cox.

RESULTADOS: A incidência de quedas foi 12,6 por mil pacientes/dia. Os fatores preditores para quedas durante a internação foram baixa escolaridade $(\mathrm{RR}=2,48$; IC95\% 1,17;5,25), polifarmácia( $\mathrm{RR}=4,42 ; \mathrm{IC} 95 \% 1,77 ; 11,05)$, presença de disfunção visual $(\mathrm{RR}=2,06$; IC95\% 1,01;4,23) e de marcha e equilíbrio ( $\mathrm{RR}=2,95$; IC95\% $1,22 ; 7,14)$, incontinência urinária $(\mathrm{RR}=5,67 ; \mathrm{IC} 95 \% 2,58 ; 12,44)$ e uso de laxativos $(\mathrm{RR}=4,21$; IC95\% 1,15;15,39) e antipsicóticos $(\mathrm{RR}=4,10 ; \mathrm{IC} 95 \%$ 1,38;12,13).

CONCLUSÕES: A incidência de quedas dos idosos hospitalizados é alta. Os fatores preditores encontrados foram baixa escolaridade, polimedicação, presença de disfunção visual, de marcha e equilíbrio, incontinência urinária e uso de laxativos e antipsicóticos. São necessárias medidas de prevenção de quedas nos hospitais a fim de reduzir a incidência desse evento.

DESCRITORES: Idoso. Acidentes por Quedas. Fatores de Risco. Estudos de Coortes.

\section{INTRODUCTION}

For the older population, falls can happen in various situations and environments, such as houses, public spaces, and institutions. In general, institutionalized older adults, both in hospitals or in long-stay institutions, fall more often than those living in the community. Each year, approximately $30.0 \%$ to $50.0 \%$ of persons living in institutions suffer falls and about $40.0 \%$ of them experience recurrent falls..$^{12,21}$ In hospitals, the incidence of falls for persons aged 60 or over ranges between three and seven falls per 1,000 patients/day $\mathrm{y}^{6,7,22}$ and is related to factors intrinsic to the patient, such as age, balance and gait deficit, urinary incontinence, compromised cognitive status, and others. ${ }^{5,7,22}$ Extrinsic factors are represented by some conditions of the hospital environment and situations related to healthcare by the hospital medical staff, such as use of hypnotic drugs, anxiolytics, and antiparkinsonism medicines, among others. ${ }^{19,20}$

Falls can cause fractures, soft tissue injuries, bruises, lacerations and death. ${ }^{6,22}$ In addition to the physical damage, caregivers and family near these seniors have higher prevalence of psychoemotional disorders. ${ }^{14,19}$ Accidents by falls in hospitals also cause damage to the institutions, since they are associated with increased hospital stay and increased use of health resources. For example, in 2007, the average cost to treat the consequences of a fall of an older inpatient in a hospital in the United States was of USD $29,363 .^{24}$ No data on these costs for Brazil are available.

Studies on falls in hospitals mainly investigated the characteristics of patients and falls. ${ }^{1,18}$ Studies on falls of older inpatients mainly researched associated factors. $5,6,13,14,19,20$ Few studies determined the incidence and factors associated with falls of older inpatients and utilized cohort follow-up studies. ${ }^{7,22}$ Designs of this kind can bring greater understanding of predicting factors of falls than most observational studies.

The objective of this study was to estimate the incidence and predicting factors of falls for older inpatients.

\section{METHODS}

This concurrent prospective cohort study was conducted from March to August 2013 in three large general hospitals under contract of the Unified Health System (SUS) in the city of Cuiaba, MT, Midwestern Brazil. These hospitals were selected because they have 
medical units in which a great number of seniors are admitted and the time of hospital stay is usually longer when compared to other hospitals.

The participants were all patients, aged 60 or over, admitted during the study period to 98 beds of the medical clinics. During this period, 224 seniors were admitted. After application of the Mini Mental State Examination (MMSE), ${ }^{4}$ three seniors were excluded because they had compromised mental capacity and had no companion to respond instead. Daily visits were conducted to three hospitals to verify the admissions of patients aged 60 years or over in the prior $24 \mathrm{~h}$. This was considered the starting point for the follow-up of the cohort. Data on patients were obtained from medical records, interview, and application of tests for cognitive status, vision, balance and gait, and hearing with use of scales.

To evaluate the exposure variables, we used a questionnaire that included sociodemographic information: sex (female; male), age (categorized in years and later recategorized in age groups), education (illiterate; one year of education or more), income (minimum wages), and marital status (married; widowed/single/divorced). In addition, data on health status were collected: history of falls (yes; no), number of morbidities (only one; two or more), type of morbidity, number of medications used (one to six; seven or more), type of medications, and use of prosthesis or orthosis (yes; no). Were also evaluated: hearing acuity of the participants by whisper test ${ }^{16}$ (impairment; no impairment), visual acuity by Jaeger Card $^{17}$ (impairment; no impairment), gait and balance disorder using the gait and balance scale of Tinetti ${ }^{23}$ (impairment; no impairment), and mental capacity by $\mathrm{MMSE}^{4}$ (compromised; non-compromised).

The older inpatients were visited daily and asked about the occurrence of fall (outcome). In this study, fall was regarded as the event referred to by the older inpatient or companion after the following question: Did you suffer some kind of fall today? When the response was positive, we conducted a new interview with questions about the characteristics and consequences of the falls.

The collected data was entered to EpiInfo 2000 version 3.5.2 and typos were corrected by the application Data Compare of the same program. Later, a descriptive, bivariate and multiple analysis was carried out using the Statistical Package for Social Sciences 18.0 (SPSS). To measure the ratios for incidence rate between those exposed and nonexposed to fall, the incidence density method was chosen, which calculates the number of persons/day of exposure from the time the fall (fail) occurred (or not). The observation period for each individual was calculated taking into account the date of admission, extending to the date the fall, discharge, or death occurred. Individuals who suffered no fall during the follow-up period were classified as censored.
Time until occurrence of the fall was analyzed by the Kaplan-Meier method, which estimates the function and curve of survival.

We conducted multiple analysis by Cox model, obtaining the ratio of hazards in the bivariate and multivariate analysis for the variables with proportionality of hazards over time. We used the method of stepwise backward removal of variables, based on a set of initial variables. The initial set comprised the variables that, individually, had $\alpha<0.20$. The associations that had $\alpha<0.05$ were considered as statistically significant.

The study was approved by the Research Ethics Committee of Hospital Universitário Julio Muller (Protocol 206.880/2013 approved on February 27, 2013). All participants signed an informed consent form.

\section{RESULTS}

Results of the survival analysis (life table) are presented in Table 1. The incidence of falls was 12.6 per 1,000 patients/day. Overall survival obtained by the Kaplan-Meier estimate was $64.0 \%$ at the end of the study period, while between seven and 14 days the estimated survival was $82.0 \%$. At the end of follow-up, 35 patients $(15.8 \%)$ had suffered falls.

In the bivariate analysis of sociodemographic variables (Table 2), only the variable low education level (illiterate) had a statistically significant association $(\mathrm{RR}=2.03 ; 95 \%$ CI 1.05;3.93).

Tables 3 and 4 include the bivariate analysis of health status variables. Table 3 shows the variables that remained associated as fall predictors, number of morbidities (two or more) $(\mathrm{RR}=3.70$; $95 \%$ CI $1.54 ; 8.88)$, urinary incontinence $(\mathrm{RR}=6.80$; 95\% CI 3.38;13.64), decline in cognitive status $(\mathrm{RR}=3.21 ; 95 \% \mathrm{CI} 1.63 ; 6.35)$, alteration in balance and gait $(\mathrm{RR}=5.30 ; 95 \% \mathrm{CI} 2.32 ; 12.09)$, visual impairment $(\mathrm{RR}=1.92 ; 95 \% \mathrm{CI} 1.00 ; 3.71)$, and use of prosthesis and/or orthosis ( $\mathrm{RR}=4.09 ; 95 \% \mathrm{CI} 1.92 ; 8.69)$. Moreover, hypertension $(\mathrm{RR}=3.11 ; 95 \% \mathrm{CI} 0.75 ; 12.9)$ and diabetes $(\mathrm{RR}=1.86 ; 95 \% \mathrm{CI} 0.96 ; 3.60)$ had borderline statistical associations, with p-values near 0.05 .

In the bivariate analysis on use of medicines and fall, the variables associated to fall were polypharmacy $(\mathrm{RR}=3.19 ; 95 \% \mathrm{CI} 1.33 ; 7.65)$, use of hypoglycemic agents $(\mathrm{RR}=2.22 ; 95 \% \mathrm{CI} 1.12 ; 4.40)$, use of anxiolytics $(\mathrm{RR}=4.36 ; 95 \% \mathrm{CI} 1.84 ; 10.30)$, and use of antipsychotics $(\mathrm{RR}=3.51 ; 95 \% \mathrm{CI} 1.38 ; 8.89)$. Antihypertensives ( $\mathrm{RR}=2.74 ; 95 \%$ CI $0.66 ; 11.41$ ), laxatives ( $\mathrm{RR}=3.16 ; 95 \% \mathrm{CI} 0.99 ; 10.12)$, and anticonvulsants $(\mathrm{RR}=3.16 ; 95 \% \mathrm{CI} 0.99 ; 10.12)$ had borderline statistical associations (Table 4). 
Table 1. Life table for time until the occurrence of the falls of older inpatients. Cuiaba, MT, Midwestern Brazil, 2013. ( N = 221)

\begin{tabular}{|c|c|c|c|c|c|c|c|c|}
\hline \multirow{2}{*}{$\begin{array}{l}\text { Time } \\
\text { (days) }\end{array}$} & I & Censoring & $\begin{array}{c}\text { Exposed } \\
\text { to risk }\end{array}$ & $\begin{array}{c}\text { Occurrence of } \\
\text { the event }\end{array}$ & $\begin{array}{l}\text { Occurrence of } \\
\text { the event }\end{array}$ & Survival & $\begin{array}{c}\text { Accumulated } \\
\text { survival }\end{array}$ & $\begin{array}{c}\text { Standard error } \\
\text { of survival }\end{array}$ \\
\hline & $\mathrm{N}$ & $\mathrm{n}$ & $\mathrm{n}$ & $\mathrm{n}$ & $\%$ & $\%$ & $\%$ & $\%$ \\
\hline$<7$ & 221 & 51 & 196 & 24 & 0.12 & 0.88 & 0.88 & 0.03 \\
\hline 7 to $<14$ & 146 & 75 & 109 & 7 & 0.06 & 0.94 & 0.82 & 0.03 \\
\hline 14 to $<21$ & 64 & 37 & 46 & 1 & 0.02 & 0.98 & 0.80 & 0.02 \\
\hline$\geq 21$ & 26 & 23 & 15 & 3 & 0.20 & 0.80 & 0.64 & 0.13 \\
\hline
\end{tabular}

Table 2. Distribution of older inpatients that suffered falls by hospitalization time incidence density according to sociodemographic variables. Cuiaba, MT, Midwestern Brazil, 2013.

\begin{tabular}{|c|c|c|c|c|c|c|}
\hline Variable & Fall & Person/time & Incidence ${ }^{a}$ & $\mathrm{RR}$ & $95 \% \mathrm{Cl}$ & p \\
\hline \multicolumn{7}{|l|}{ Sex } \\
\hline Male & 18 & 1,568 & 11.48 & 1 & & \\
\hline Female & 17 & 1,212 & 14.03 & 1.22 & $0.63 ; 2.36$ & 0.550 \\
\hline \multicolumn{7}{|l|}{ Age group (years) } \\
\hline 60 to 79 & 25 & 2,162 & 11.56 & 1 & & \\
\hline$\geq 80$ & 10 & 618 & 16.18 & 1.40 & $0.68 ; 2.90$ & 0.364 \\
\hline \multicolumn{7}{|l|}{ Marital status } \\
\hline Married & 14 & 1,744 & 12.04 & 1 & & \\
\hline Divorced/Widowed/Single & 21 & 1,036 & 13.51 & 0.89 & $0.45 ; 1.74$ & 0.736 \\
\hline \multicolumn{7}{|l|}{ Education } \\
\hline$\geq 1$ year of education & 17 & 1,828 & 9.28 & 1 & & \\
\hline Illiterate & 18 & 952 & 18.91 & 2.03 & $1.05 ; 3.93$ & 0.031 \\
\hline \multicolumn{7}{|l|}{ Income of older inpatient } \\
\hline$>1 \mathrm{MW}$ & 6 & 308 & 19.48 & 1 & & \\
\hline 0 to $1 \mathrm{MW}$ & 29 & 2,472 & 11.73 & 0.60 & $0.25 ; 1.44$ & 0.250 \\
\hline
\end{tabular}

RR: Relative risk; MW: Minimum wage of BRL 678.00 or USD 332.00 (www.dieese.org.br)

${ }^{a}$ Per 1,000 persons/time.

Statistically significant values are presented in bold.

In the final model of the multivariate Cox regression (Table 5), the predicting variables for falls were illiteracy $(\mathrm{RR}=2.48 ; 95 \% \mathrm{CI} 1.17 ; 5.25)$, polypharmacy $(\mathrm{RR}=4.42 ; 95 \% \mathrm{CI} 1.77 ; 11.05)$, visual impairment $(\mathrm{RR}=2.06 ; 95 \% \mathrm{CI} 1.01 ; 4.23)$, gait and balance impairment $(\mathrm{RR}=2,95 ; 95 \% \mathrm{CI} 1,22 ; 7,14)$, urinary incontinence $(\mathrm{RR}=5.67 ; 95 \% \mathrm{CI} 2.58 ; 12.44)$, use of laxatives $(\mathrm{RR}=4.21 ; 95 \% \mathrm{CI} 1.15 ; 15.39)$ and use of antipsychotics $(\mathrm{RR}=4.10 ; 95 \% \mathrm{CI} 1.38 ; 12.13)$.

\section{DISCUSSION}

The incidence of falls of 12.6 per 1,000 patients/day (overall survival $=42.0 \%$ ) found in this study was significantly greater than in previous studies. ${ }^{7,22}$ In a prospective longitudinal study with 620 older inpatients aged 70 and over in Turin (Italy), followed for one year, incidence of 6.0 falls per 1,000 patients/day was observed. ${ }^{7}$ In a cohort of 2,973 seniors aged 65 and over, admitted to a hospital in Japan and followed for two years, incidence was 3.8 falls per 1,000 patients/day. ${ }^{22}$ This difference is probably due to the context in which the falls occurred. In the hospitals surveyed in this study, preventive measures against falls of patients are still based on observation and judgment of the professionals who assist them. Strategies to prevent falls of inpatients need to be based on established programs, which use validated protocols that identify persons at risk and implement risk reduction actions. Currently, evidence indicates that multifactorial interventions reduce the rates of falls of seniors both in hospitals and in the community. ${ }^{15}$

In this study, low educational level was associated with fall. One possible explanation is that older individuals with low levels of education perceive less and worry less about healthcare, and have less ability to engage in health recovery, which results in increased risk of falls. ${ }^{25}$ Additionally, studies indicate that the educational level influences the spatial perception of the older adult so that, when performing visual search tasks, individuals 
Table 3. Distribution of older inpatients that suffered falls by hospitalization time incidence density according to health status variables. Cuiaba, MT, Midwestern Brazil, 2013.

\begin{tabular}{|c|c|c|c|c|c|c|}
\hline Variable & Fall & Persons/time & Incidence $^{\mathrm{a}}$ & RR & $95 \% \mathrm{Cl}$ & $\mathrm{p}$ \\
\hline \multicolumn{7}{|l|}{ No. of morbidities } \\
\hline 1 & 6 & 1,205 & 4.98 & 1 & & \\
\hline$\geq 2$ & 29 & 1,575 & 18.41 & 3.70 & $1.54 ; 8.88$ & 0.002 \\
\hline \multicolumn{7}{|l|}{ Type of morbidity } \\
\hline \multicolumn{7}{|l|}{ Hypertension } \\
\hline No & 2 & 441 & 4.53 & 1 & & \\
\hline Yes & 33 & 2,339 & 14.11 & 3.11 & $0.75 ; 12.92$ & $0.066^{\mathrm{b}}$ \\
\hline \multicolumn{7}{|l|}{ Diabetes } \\
\hline No & 19 & 1,914 & 9.95 & 1 & & \\
\hline Yes & 16 & 866 & 18.47 & 1.86 & $0.96 ; 3.60$ & 0.061 \\
\hline \multicolumn{7}{|l|}{ Urinary incontinence } \\
\hline No & 24 & 2,609 & 9.20 & 1 & & \\
\hline Yes & 11 & 176 & 62.50 & 6.80 & $3.38 ; 13.64$ & $<0.001$ \\
\hline \multicolumn{7}{|l|}{ Mental capacity } \\
\hline Noncompromised & 13 & 1,821 & 7.14 & 1 & & \\
\hline Compromised & 22 & 959 & 22.94 & 3.21 & $1.63 ; 6.35$ & $<0.001$ \\
\hline \multicolumn{7}{|l|}{ Balance and gait } \\
\hline No impairment & 7 & 1,584 & 4.42 & 1 & & \\
\hline Impairment & 28 & 1,196 & 23.41 & 5.30 & $2.32 ; 12.09$ & $<0.001$ \\
\hline \multicolumn{7}{|l|}{ Visual acuity } \\
\hline No impairment & 19 & 1,932 & 9.87 & 1 & & \\
\hline Impairment & 16 & 848 & 18.87 & 1.92 & $1.00 ; 3.71$ & 0.049 \\
\hline \multicolumn{7}{|l|}{ Hearing acuity } \\
\hline No impairment & 32 & 2,432 & 13.16 & 1 & & \\
\hline Impairment & 3 & 348 & 8.62 & 0.66 & $0.20 ; 2.12$ & 0.345 \\
\hline \multicolumn{7}{|c|}{ Use of prosthesis and/or orthosis } \\
\hline No & 9 & 1,629 & 5.52 & 1 & & \\
\hline Yes & 26 & 1,151 & 22.59 & 4.09 & $1.92 ; 8.69$ & $<0.001$ \\
\hline
\end{tabular}

RR: Relative risk

a Per 1,000 persons/time.

b Fisher test.

Statistically significant values are presented in bold.

with low educational level require more time, make more mistakes, and reach fewer targets when compared to individuals with high educational level. ${ }^{8}$

Association of visual impairment with risk of falls is consistent with the results of some studies showing that older inpatients with lower visual acuity fall more. ${ }^{5-7,22}$ Alterations in the eyes resulting from the aging process include gradual loss of visual acuity, in addition to decreased peripheral vision, visual accommodation, and depth perception, slowness in processing visual information, and difficulties to scan an area. Since the visual system plays an important role in postural control, its dysfunctions can impair the maintenance of balance. ${ }^{3}$
In this study, poor condition of balance and gait was a predicting variable for falls. Factors associated with impaired mobility have been identified as being associated with increased risk of falls for older inpatients. ${ }^{6,7}$ Aging is characterized by gradual motor decline and decreased muscle strength, affecting work capacity, motor activity, and adaptability to the environment, which contributes to the occurrence of falls. ${ }^{11}$

Urinary incontinence was prominent as the main factor associated with falls of older inpatients. This condition affects half of the older living in long-term care institutions or hospitalized patients. ${ }^{9}$ Some studies even classify urinary incontinence and fall as "Giants of Geriatrics", i.e., major morbidities in triggering different pathological processes in the older people. ${ }^{10}$ 
Table 4. Distribution of older inpatients that suffered falls by hospitalization time incidence density according to medication variables. Cuiaba, MT, Midwestern Brazil, 2013.

\begin{tabular}{|c|c|c|c|c|c|c|}
\hline Variable & Fall & Persons/time & Incidence $^{a}$ & $\mathrm{RR}$ & $95 \% \mathrm{Cl}$ & $\mathrm{p}$ \\
\hline \multicolumn{7}{|c|}{ No. of medications } \\
\hline 1 to 6 & 6 & 1,246 & 4.81 & 1 & & \\
\hline$\geq 7$ & 29 & 1,534 & 18.90 & 3.19 & $1.33 ; 7.65$ & 0.006 \\
\hline \multicolumn{7}{|c|}{ Class of medicine } \\
\hline \multicolumn{7}{|c|}{ Antihypertensives } \\
\hline No & 2 & 397 & 5.04 & 1 & & \\
\hline Yes & 33 & 2,383 & 13.85 & 2.74 & $0.66 ; 11.41$ & $0.067^{b}$ \\
\hline \multicolumn{7}{|c|}{ Hypoglycemic agents } \\
\hline No & 13 & 1,579 & 8.23 & 1 & & \\
\hline Yes & 22 & 1,201 & 18.32 & 2.22 & $1.12 ; 4.40$ & 0.018 \\
\hline \multicolumn{7}{|c|}{ Diuretics } \\
\hline No & 22 & 1,670 & 13.17 & 1 & & \\
\hline Yes & 13 & 1,110 & 11.71 & 1.12 & $0.57 ; 2.22$ & 0.735 \\
\hline \multicolumn{7}{|c|}{ Anxiolytics } \\
\hline No & 29 & 2,654 & 10.93 & 1 & & \\
\hline Yes & 6 & 126 & 47.62 & 4.36 & $1.84 ; 10.30$ & $<0.001$ \\
\hline \multicolumn{7}{|c|}{ Antipsychotics } \\
\hline No & 30 & 2,654 & 11.30 & 1 & & \\
\hline Yes & 5 & 126 & 39.68 & 3.51 & $1.38 ; 8.89$ & $0.019^{b}$ \\
\hline \multicolumn{7}{|c|}{ Laxatives } \\
\hline No & 32 & 2,700 & 11.85 & 1 & & \\
\hline Yes & 3 & 80 & 37.50 & 3.16 & $0.99 ; 10.12$ & $0.077^{b}$ \\
\hline \multicolumn{7}{|c|}{ Antihistamines } \\
\hline No & 22 & 2,000 & 11.00 & 1 & & \\
\hline Yes & 13 & 780 & 16.67 & 1.51 & $0.77 ; 2.99$ & 0.229 \\
\hline \multicolumn{7}{|c|}{ Anticonvulsants } \\
\hline No & 32 & 2,700 & 11.85 & 1 & & \\
\hline Yes & 2 & 80 & 37.50 & 3.16 & $0.99 ; 10.12$ & $0.077^{b}$ \\
\hline
\end{tabular}

RR: Relative risk

a Per 1,000 persons/time.

${ }^{\mathrm{b}}$ Fisher test.

Statistically significant values are presented in bold.

Urinary incontinence is believed to contribute to increased risk of falls for the older adult because these patients need to get up more times to use the bathroom. ${ }^{25}$

Polypharmacy was also associated with the occurrence of fall. Similarly to this finding, some studies have found associations between use of medicines and occurrence of falls and recurrent falls. ${ }^{19,20}$ Polypharmacy, for the older adults, can lead to more falls as it increases the incidence of side effects and drug interactions. ${ }^{19}$

Regarding the specific pharmacological treatments, the medicines associated with falls were antipsychotics and laxatives. Antipsychotics lead to higher incidence of drowsiness, abnormal gait, dizziness and loss of consciousness and, hence, higher risk of fall..$^{19,20}$ As for laxatives, use of these medicines causes the older person to get up several times to use the bathroom, often without assistance, which contributes to greater occurrence of falls. In a systematic review study, the authors observed that older individuals make greater use of laxatives, are more confined to bed, and have a higher prevalence of diseases that predispose fall, such as Parkinson's disease. ${ }^{2}$

The epidemiological design of this study has greater validity and precision than observational studies, since the exposures are evaluated at the moment of occurence, not having to resort to the memory of individuals. Furthermore, the design allows the assessment of the 
Table 5. Cox proportional hazards regression for the incidence of falls of older inpatients. Cuiaba, MT, Midwestern Brazil, 2013.

\begin{tabular}{|c|c|c|c|}
\hline Variable & $\mathrm{RR}$ & $95 \% \mathrm{Cl}$ & $\mathrm{p}$ \\
\hline \multicolumn{4}{|l|}{ Education } \\
\hline$\geq 1$ year of education & 1 & & \\
\hline Illiterate & 2.48 & $1.17 ; 5.25$ & 0.018 \\
\hline \multicolumn{4}{|l|}{ No. of medications } \\
\hline 1 to 6 & 1 & & \\
\hline$\geq 7$ & 4.42 & $1.77 ; 11.05$ & 0.001 \\
\hline \multicolumn{4}{|l|}{ Urinary incontinence } \\
\hline No & 1 & & \\
\hline Yes & 5.67 & $2.58 ; 12.44$ & $<0.001$ \\
\hline \multicolumn{4}{|l|}{ Visual acuity } \\
\hline No impairment & 1 & & \\
\hline Impairment & 2.06 & $1.01 ; 4.23$ & 0.048 \\
\hline \multicolumn{4}{|l|}{ Balance and gait } \\
\hline No impairment & 1 & & \\
\hline Impairment & 2.95 & $1.22 ; 7.14$ & 0.016 \\
\hline \multicolumn{4}{|l|}{ Laxatives } \\
\hline No & 1 & & \\
\hline Yes & 4.21 & $1.15 ; 15.39$ & 0.030 \\
\hline \multicolumn{4}{|l|}{ Antipsychotics } \\
\hline No & 1 & & \\
\hline Yes & 4.10 & $1.38 ; 12.13$ & 0.011 \\
\hline
\end{tabular}

RR: Relative risk

\section{REFERENCES}

1. Abreu C, Mendes A, Monteiro J, Santos FR. Quedas em meio hospitalar: um estudo longitudinal. Rev Latino-Am Enfermagem. 2012;20(3):597-603. DOI:10.1590/S0104-11692012000300023

2. Bloch $F$, Thibaud $M$, Dugué $B$, Brèque $C$, Rigaud AS, Kemoun G. Laxatives as a risk factor for iatrogenic falls in elderly subjects: myth or reality? Drugs Aging. 2010;27(11):895-901. DOI:10.2165/11584280-000000000-00000

3. Boutin T, Kergoat MJ, Latour J, Massoud F, Kergoat H. Vision in the global evaluation of older individuals hospitalized following a fall. J Am Med Dir Assoc. 2012;13(2):187.e15-9. DOI:10.1016/j.jamda.2011.04.003

4. Brucki SMD, Nitrini R, Caramelli P, Bertolucci PHF, Okamoto IH. Sugestões para o uso do mini-exame do estado mental no Brasil. Arq Neuro Psiquiatr. 2003;61(3B):777-81. DOI:10.1590/S0004-282X2003000500014

5. Chen X, Van Nguyen H, Shen Q, Chan DK. Characteristics associated with recurrent falls among the elderly within aged-care wards in a tertiary hospital: the effect of cognitive impairment. Arch Gerontol Geriatr. 2011;53(2):e183-6. DOI:10.1016/j.archger.2010.08.012 risks with no influence of the presence of the event, in this case, the occurrence of fall.

Conversely, cohort studies may have as limitation the loss of participants during follow-up, especially in population-based studies. However, as this study was hospital-based and monitoring was conducted by the lead researcher, such losses were minimized.

The question asked daily to verify the occurrence of falls among the older person could lead them to refer to any event similar to fall as "fall", even though it had not occured. However, conducting additional interviews concerning the characteristics and consequences of falls enabled validating the occurrence of this event as defined in the literature.

This study showed significant epidemiological data on falls of older inpatients, indicating the main predicting factors. It should be emphasized that direct and indirect causes in the hospital environment that led to falls of older inpatients were not investigated.

The incidence of falls of older inpatients is high. Low educational level, polypharmacy, visual impairment, gait and balance impairment, urinary incontinence and use of laxatives and antipsychotics were associated with occurrence. These results reinforce the need for more research on falls of older inpatients in hospital environments and fall prevention measures involving different healthcare professionals, managers, and family members.

6. Chen XL, Liu YH, Chan DK, Shen Q, Van Nguyen $\mathrm{H}$. Characteristics associated with falls among the elderly within aged care wards in a tertiary hospital: a retrospective. Chin Med J (Engl). 2010;123(13):1668-72.

7. Corsinovi L, Bo M, Ricauda Aimonino N, Marinello R, Gariglio F, Marchetto C, Gastaldi L, et al. Predictors of falls and hospitalization out comes in elderly patients admitted to an acute geriatric unit. Arch Gerontol Geriatr. 2009;49(1):142-5. DOI:10.1016/j.archger.2008.06.004

8. Custódio EB, Malaquias Júnior J, Voos MC. Relação entre cognição (função executiva e percepção espacial) e equilíbrio de idosos de baixa escolaridade. Fisioter Pesq. 2010;17(1):46-51. DOI:10.1590/S1809-29502010000100009

9. Damián J, Pastor-Barriuso R, Valderrama-Gama E, Pedro-Cuesta J. Factors associated with falls among older adults living in institutions. BMC Geriatrics. 2013;13:6. DOI:10.1186/1471-2318-13-6

10. Foley AL, Loharuka S, Barrett JA, Mathews R, Williams $\mathrm{K}, \mathrm{McG}$ rother $\mathrm{CW}$, et al. Association between the Geriatric Giants of urinary incontinence and falls in older people using data from the Leicestershire MRC Incontinence Study. Age Ageing. 2012;41(1):35-40. DOI:10.1093/ageing/afr125 
11. Gomes GAO, Cintra FA, Batista FS, Neri AL, Guariento ME, Sousa MLR, et al. Elderly outpatient profile and predictors of falls. Sao Paulo Med J. 2013;131(1):13-8. DOI:10.1590/S1516-31802013000100003

12. Gonçalves LG, Vieira ST, Siqueira FV, Hallal PC. Prevalência de quedas em idosos asilados do município de Rio Grande, Brasil. Rev Saude Publica. 2008;42(5):938-45. DOI:10.1590/S0034-89102008000500021

13. Härlein J,Halfens RJ, Dassen T, Lahmann NA. Falls in older hospital inpatients and the effect of cognitive impairment: a secondary analysis of prevalence studies. J Clin Nurs. 2011;20(1-2):175-83. DOI:10.1111/j.1365-2702.2010.03460.x

14. Hill KD, Vu M, Walsh W. Falls in the acute hospital setting: impact on resource utilisation. Aust Health Rev. 2007;31(3):471-7. DOI:10.1071/AH070471

15. Karlsson MK, Vonschewelov T, Karlsson C, Cöster $\mathrm{M}$, Rosengen BE. Prevention of falls in the elderly: a review. Scand J Public Health. 2013;41(5):442-54. DOI:10.1177/1403494813483215

16. Macphee GJ, Crowther JA, McAlpine CH. A simple screening test for hearing impairment in elderly patients. Age Ageing. 1988;17(5):347-51. DOI:10.1093/ageing/17.5.347

17. Mangione CM, Phillip RS, Seddon JM, Lawrence MG, Cook EF, Dailey R, et al. Development of the "Activities of Daily Vision Scale": a measure of visual functional status. Med Care. 1992;30(12):1111-26.

18. Paiva MCMS, Paiva SAR, Berti HW, Campana AO. Caracterização das quedas de pacientes segundo notificação em boletins de eventos adversos. Rev ESC Enferm USP. 2010;44(1):134-8. DOI:10.1590/S0080-62342010000100019

19. Rhalimi M, Helou R, Jaecker P. Medication use and increased risk of falls in hospitalized elderly patients: a retrospective, case-control study. Drugs Aging. 2009;26(10):847-52. DOI:10.2165/11317610-000000000-00000

20. Shuto H, Imakyure O, Matsumoto J, Egawa T, Jiang Y, Hirakawa $\mathrm{M}$, et al. Medication use as a risk factor for inpatient falls in an acute care hospital: a case-crossover study. Br J Clin Pharmacol. 2010;69(5):535-42. DOI:10.1111/j.1365-2125.2010.03613.x

21. Stevens JA, Corso PS, Finkelstein EA, Miller TR. The costs of fatal and non-fatal falls among older adults. Inj Prev. 2006;12(5):290-5. DOI:10.1136/ip.2005.011015

22. Tanaka B, Sakuma M, Ohtani M, Toshiro J, Matsumura T, Morimoto T. Incidence and risk factors of hospital falls on long-term care wards in Japan. J Eval Clin Pract. 2012;18(3):572-7. DOI:10.1111/j.1365-2753.2010.01629.x

23. Tinetti ME. Performace- oriented assessment of mobility problems in elderly patients. / Am Geriatr Soc. 1986;34(2):119-26.

24. Woolcott JC, Khan KM, Mitrovic S, Anis AH, Marra CA. The cost of fall related presentations to the ED: a prospective, in-person, patient-tracking analysis of health resource utilization. Osteoporos Int. 2012;23(5):1513-9. DOI:10.1007/s00198-011-1764-1

25. World Health Organization. Injuries and violence: the facts. Geneva; 2010.

This study was supported by Fundação Coordenação de Aperfeiçoamento de Pessoal de Nível Superior - CAPES/MEC (REUNI scholarship granted to Abreu HCA) and by the Undergraduate Research Program of CNPq (Scholarship granted to Oliveira AD). Based on the Master's dissertation by Hellen Cristina de Almeida Abreu, titled: "Incidência e fatores associados às quedas de idosos hospitalizados", presented to the Graduate Program in Nursing Science of the Faculdade de Enfermagem of the Universidade Federal de Mato Grosso, in 2014.

The authors declare no conflict of interest. 